\title{
Kebanjaran Identity Symbol in the Novel Entitled "Pambatangan" by Jamal T. Suryanata (Structural Ethnosemiotic Studies)
}

\author{
Heppy Lismayati ${ }^{1}$, Haris Supratno ${ }^{2}$, Setya Yuwana ${ }^{3}$, Suhartono $^{4}$, Darni ${ }^{5}$, Udjang Pairin ${ }^{6}$ \\ Universitas Negeri Surabaya ${ }^{1,2,3,4,5,6}$ \\ \{heppy.19017@mhs.unesa.ac.id ${ }^{1}$, harissupratno@unesa.ac.id², setyayuwana@unesa..ac.id ${ }^{3}$, \\ suhartono@unesa.ac.id ${ }^{4}$,darni@unesa.ac.id ${ }^{5}$, udjangjw@unesa.ac.id $\left.{ }^{6}\right\}$
}

\begin{abstract}
The contemporary prose of the Banjar novel reveals the reality of the dynamic life of the Banjar people. Text in literary works contains cultural aspects that are expressed in symbols or signs as a cultural representation of society. This research is qualitative research with an ethnographic or cultural approach and a structural semiotic method that aims to reveal the identity symbol of the flood in Jamal T. Suryanata's Banjar Pambatangan. The data source of this research is the novel Pambatangan by Jamal T Suryanata which was published in 2017. The results of this study reveal 1) two religious symbols symbolize the identity of the flood in pambatangan, a) the philosophy of 40 years old when Muhammad was appointed a prophet, and b) the turban used by the teacher as a sign of humility and respect for religious leaders who are more knowledgeable. 2) cultural symbols that symbolize the identity of Kebanjaran in the fiction entitled "Pambatangan", there are three, namely a) wisa disease, namely belief in poison diseases sent by other people invisibly, b) basasuluh is a symbol in the first process of the marriage system, c) studying as a characteristic of Banjar society, 3) social symbols that symbolize the identity of floods in pambatangan, there are two, namely a) mudik ka banua and b) bakupiah.
\end{abstract}

Keywords: kebanjaran identity; structural semiotics; symbols.

\section{Introduction}

Literature work in the form of Banjar fiction could be categorized as contemporary Prose works, because written literature is included as the emerging ones, compared to oral literature, especially in Banjar society. The novel entitled "Pambatangan" by Jamal T. Suryanata is one of the local novels in the Banjar language, which reveals the reality of the changing context in the cultural and social space of the Banjar community.

Jamal T. Suryanata is one of the Banjar writers who consistently building Banjar fiction in the form of a poem, short story, and novel. Almost every year, Jamal produces a work that is strongly related to local wisdom and culture. "Pambatangan" Novel becomes the winner of the 2017 rancage literary prize. The local color of the Banjar people is quite thick in this fiction because it is closely related to people's life in general. The main content in this novel reveals the identity of the Banjar people who are religious and unyielding. 
Reality complexion of life is depicted in literary works, as well as the identity of society which is a unity that cannot stand alone. Traditionally, identity is interpreted as all the similarities that a group of people thinks, believes, and does. Socio-cultural identity has been ingrained for a group of people with similar perceptions. An individual can be classified and united because they are considered as subgroups with similar identities and adapted to each other. (Meyer, Jencsary, Hollerer, \& Barberio, 2012).

The study of the social identity of a society is considered quite important as an effort to explore the dynamic life of humans in facing various life challenges. Text structures or cultural practices have syntagmatic and paradigmatic links (Chandler, 2002). The syntagmatic element is a textual structure constructed by the author to reconstruct social reality, while the paradigmatic dimension is a contextual element that may not be used simultaneously. This means that it can apply in a community group but does not apply to other communities.

Kebanjaran identity can be seen through the socio-cultural intertwining of the Banjar people in daily life, but can also be expressed in works such as novels. Research on the Kebanjaran identity was carried out by Harisuddin (2020) entitled "Urang Banjar: Asal-usul dan Identitasnya" (Urang Banjar: Its Origin and Identity) reveals that based on historical facts, Banjar identity is formed by the relationship of heterogeneous social groups through the configuration of various tribes over hundreds of years formed through natural processes. Later, in the research by Zakiah Agus (2015) entitled "Identitas Kebanjaran Dalam Peribahasan Banjar", the results of this study reveal that in 86 proverbs consisting of 39 proverbs about behavior, 14 proverbs about work ethics, 17 proverbs about appearance, 9 proverbs about nature, and 7 proverbs about life views.

\section{Concept and Method}

Literature works are a result of linguistic creativity because it is processing word sequences to be a system of textual structure. Through the textual form, aspects that are related to human life have emerged including culture, sign, representation, and statement in the form of text. This fictional text reveals the phenomenology of everyday life in the form of language signs that produce cultural semiotics. In the structural point of view analysis traditional presentation can be seen as an analogy with sentences in a language that produces selfpresentation meaning produced by the metaphor of roles, settings, situations, texts, signs, and so on. (Chandler, 2017).

Socio-semantic network analysis offers a conceptual framework and relational methodology for the structural analysis of social and cultural relationships such as symbols, ideas, and meanings. (Basov, et all. 2020). Social and cultural activities that are always dynamic, enable the merging of relationships between social actors and cultural elements such as meaning, words, and discourse in structural linguistics that focus on the relationship between textual elements.

The social ethical system of a group is traditionally continued through symbolic symbols for easy learning. This symbol as a process of civilization inheritance is symbolized in the form of texts, colors, objects, etc. which are identified in nature, politics, morals, and religion. (Song, 2019). All of these symbols become the binding force of social order acquired through the process of the journey of human civilization which of course will continue to change which ultimately achieves the harmony of human life.

The research is a qualitative approach to ethnography or cultural and structural semiotic methods aimed at revealing the identity symbol Kebanjaran in Banjar Pambatangan fiction 
works of Jamal T. Suryanata. Structural semiotic analysis is a multidisciplinary linguistic science with a focus on the meaning and structure of the novel "Pambatangan", then reconstructed with structural theory to reveal religious symbols, cultural symbols, and social symbols. The data source of this research is the novel "Pambatangan" by Jamal T Suryanata which was published in 2017 with 237 pages published by Tahura Media. This research technique is utilizing data transcription by the identity symbol of the Banjar language into Indonesian. classifying data according to religious symbols, cultural symbols, and social symbols, then a comprehensive study with related theories, and finally concluding.

\section{Discussion}

Pambatangan is a typical livelihood term for the community, namely by floating the dissolved logs along the river to the wood processing factory on the riverbank. As in the following quote; “..., hudah parak dua hari samalaman Alan wan kawalnya nang batalu nitu umpat balarut di atas lanting batang nang panjangnya mandua puluh dapa nangitu. Siangmalam bubuhannya ni bagawi manjagai bapupuluh batang kayu galundungan...” (JTS, 2017: 135)

However, nowadays due to changes in the culture and lifestyle of the people, nowadays Pambatangan is no longer dependent on rivers, land transportation is considered to be more effective and efficient than rivers. Besides, this system change is related to the existence of a government policy to protect Kalimantan's plants and forests from illegal logging. So that the movement of the Pambatangan's livelihoods is increasingly limited, people currently carry a limited number of trunks by pick-up cars or motorbikes.

Based on those things, the novel "Pambatangan" reveals a change in the cultural context of the Banjar people. This change is seen as progress, even though in the end it will be able to shift the culture of society. This change is due to the existence of social actors who formulate relationships between cultural elements concerning certain social contexts that depend on the cultural space in which they interact. (Breiger, 2010; Basov \& Brennecke; 2017; Basov, et all, 2020). Based on this, the social and cultural orders shape one another, thus producing a new culture.

Specifically, the novel "Pambatangan" tells the life of a character named Alan from adolescence to adulthood who is full of dynamic twists and turns of life with problems and conflicts related to Banjar religiosity, local wisdom, and the socio-cultural relations of the Banjar people. Through the novel, "Pambatangan", depicts symbols of the Banjar people of Kabanjaran identity which include religious symbols, cultural symbols, and social symbols.

\subsection{Religious Symbol of Kebanjaran Identity in the Novel entitled "Pambatangan"}

\section{a) Data 1}

Pitua urang bahasa tu maningau lawan umur Nabi wayah sidin diangkat jadi Rasulullah (SR1, 2017: 10) The religious symbol in the $1^{\text {st }}$ Data is the age of the Prophet Muhammad when he was appointed as a prophet, namely 40 years, in this phase the Banjar people believe that at this age humans must be better than before in all aspects of life including, religion, morals, and the economy. A cultural system refers to a set of beliefs and values from a group of people that can be identified from generation to generation and which are embodied in different symbols, languages, and practices. (Dockery, 2009; Herlina, et all., 2017). 


\section{b) Data 2}

Urang nang dikiau "mualim" atawa "guru” tu, janaki ja tunggal ikungan, musti kadada nang waniny babulang- malilit kain surban di kupala. (SR, 2017: 57) Data 2 shows a religious symbol in the form of a turban which is usually used by religious leaders. In Banjar society, not all religious leaders have the authority to wear a turban because it is a form of humility towards religious leaders who are more respected in particular who are considered to have more qualified religious knowledge. While mualim or teachers are religious figures in everyday society, such as leading prayers, teaching the Koran, lecturing from house to house, or surau (mosque) with a smaller scope, while Tuan Guru is a religious figure who is highly respected for his knowledge or title.

\subsection{Cultural Symbols as Kebanjaran Identity in "Pambatangan" Novel}

\section{a) Data 3}

Suwah jua Alan mandatangi urang pintar di Kapuas, sidin mamadahakan lamun inya sabujurnya kana wisa haja. Tagal, jar sidin pulang, panyakit bisa mambahayakan jua... Lamun bubuhan duktur hudah manyarah, baarti inya musti batamba kampung haja. (SB, 2017: 166) The $3^{\text {rd }}$ Data shows cultural symbols in the medical and disease systems found in the Banjar community. Wisa disease or witchcraft which is believed to be poison (Jumadi, et all, 2017), wisa is medically similar to hepatitis (Saefudin dan Maryadi, 2018). If indeed the wisa in question cannot be cured medically, then the treatment is carried out employing the Batatamba method either using mantras or other rituals such as batimung as part of the traditional medicine of the Banjar and Dayak tribes. (Saefudin dan Maryadi, 2018). The natural potential of Kalimantan which is abundant in natural products contributes to a traditional medicine system because the ingredients used come from nature and the knowledge process is associated with certain diseases.

\section{b) Data 4}

Makanyaam urang bahari tu basusuluh dahulu hanyar wani bapara. (SB2, 2017: 178) In the Banjar community marriage system, the term basasuluh is known as the first stage in the process of proposing for a girl to seek information. Basasuluh is carried out by a family delegate who has experience in investigating all aspects of the girl's life, whether someone has applied or not, the main factor in determining the selection of this girl is her family origin and personality. (Ideham, et all, 2020).

\section{c) Data 5}

Di manakah, di manakah, nang musti sakulah. Musti manuntut ilmu. Nangitu wajib hukumnya. ... (SB3, 2017: 87) Through the $5^{\text {th }}$ data above, it shows the cultural symbol of the Banjar people, namely studying. This is based on the belief in religious principles which recommends continuing to study science, religious knowledge, and knowledge in the world. This is because the priority of the Banjar people is to have the peace of living in this world as well as safety in the hereafter. 


\title{
3.3 Social Symbol as Kebajaran Identity in "Pambatangan" Novel
}

\begin{abstract}
a) Data 6
"Bubuhan kakawalan Aman tu rancak inya bulikan ka banua. Paling kada, kar bubuhannya tu, satahun sakali wayah Ari Raya Puasa atawa pas bamaulid di kampung. kita pang pabilaam bulikan, ma?" (SB1, 2017:31) The social symbol of bulikan ka banua in the data 6 shows the community's habit of going home with the aim of re-establishing the relationship as well as the right time to rest after being filled with work routines. The Banjar people know the term madam, which is migrating to people's villages to work, then at important moments, such as the big religious commemoration of Eid al-Fitr or Eid al-Adha they will return to the village to meet their parents and relatives. The analysis on social networks focuses on social bonds between social actors that connect the intra-group level to the inter-group level that builds larger social structures such as social organizations and movements. (Borgatti \& Halgin, 2011; Basov, et all, 2020)
\end{abstract}

\section{b) Data 7}

... Lantaran di kampung kami tu hudah jadi kabiasaan urang lamun sumbahyang musti bakupiah, jadi mun kada bakupiah baarti balain pada diurang. (SS1, 2017: 66) Kupiah or the cap is a cultural symbol of the Banjar people, which leads to a social symbol. The cap is a religious instrument that is used at times of worship or prayer. However, if we examine deeply, the use of the cap in the Banjar community has a very positive social symbol. Using a cap when praying is not a mandatory religious suggestion, but it leads to a social morality which is highly recommended by Religion. The custom in the Banjar community is that if you pray always using a kupiah, it must be followed to respect the customs of the local community because if you don't use it it is feared that it will cause a bad view from the community. After all, it is different from the local community. This is the main factor that the cap becomes a social symbol because it will create a peaceful social system without any negative prejudice.

\section{Closing}

\subsection{Conclusion}

Symbols in society are important things to always be studied and known because they will ultimately reveal the cultural aspects of society through the historical process of civilization. This research reveals the symbols that become the Kabanjaran identity in the fiction of Jamal T. Suryanata entitled "Pambatangan". The results of this study reveal three aspects of symbols including religious symbols, cultural symbols, and social symbols, as follows:

a. Two religious symbols symbolize the identity of flood in pambatangan, namely the philosophy of 40 years old when Muhammad was appointed as a prophet who always reminded the Banjar people to have better morals and personalities and the symbol of the turban used by the teacher as a sign of humility and respect for religious figures who more knowledgeable.

b. Three cultural symbols symbolize the identity of kebanjaran in the fictional pambatangan, namely 1) Wisa disease, namely belief in poisonous diseases sent by other people unseen, 2) basasuluh is a symbol in the marriage system to find out the identity of 
the prospective bride before being proposed, especially in the aspect of personality and family origins, 3) studying as a characteristic of the Banjar people who always learn to achieve happiness in the world and safety in the hereafter

c. Two social symbols symbolize the Kabanjaran identity in "Pambatangan", namely 1) Mudik ka banua at the moment of a religious event to meet with family and relatives to connect, 2) bakupiah when praying means a social form to respect the customs and habits of the community so that they are well-socialized.

\subsection{Suggestion/Discussion}

This research has a limited scope only on symbols that follow objects or words, while if examined through more specialized disciplines such as religious, cultural, and social theories singularly will certainly reveal different results. Hopefully, the results of this study will contribute to being able to explore more comprehensively the symbols of culture contained in society as a complex ideological system.

\section{References}

[1] Basov, N., \& Brennecke, J. 2017. Duality Beyond Duads: Multiplex Patterning of Social Ties and Cultural Meaning. In P. Groenewegen, J. Ferguson, C. Moser, J.W

[2] Basov, Nikita, et all. 2020. Socio-semantic and other dualities. Journal Poetics. Vol. 78.

[3] Borgati, S.P., \& Halgin, D.S. 2011. On Network Theory. Organization Science , 22, 1168-1181.

[4] Breiger, R. L., 2010. Dualities of Culture and Structure: Seeing through cultural holes. In J, Fuhse , \& S. Mutzel (Eds.). Relationale Soziologie (pp.37-47). Springer.

[5] Chandler, Daniel. 2002. Semiotics the Basic second edition. New York : Routledge.

[6] Chandler, Daniel. 2017. Semiotics the Basic third edition. New York : Routledge.

[7] Herlina., Andayani., Herman., and Setiawan, Budi. 2017. The Realtion of Form and Aspect of Non-Verbal Symbol of Gawai Daak Ritual with Dayak Society Life Tradition and Its Use in Regional Literature Learning in West Kalimantan. Science, Engineering, Education, and Development Studies (SEEDs). Conference Series Faculty Of Teacher Training And Education Sebelas Maret University. Vol.1, No. 1.

[8] Jumadi., Zulkifli., dan Noortyani, Rusma. 2017. Antropolinguistik dalam Mantra Dayak Maanyan di Kalimantan Selatan. Jurnal Bahasa, Sastra dan Pembelajarannya. Vol. 7, No. 1, Hal: 35-49.

[9] Saefuddin dan Maryadi, Sisva. 2018. Tradisi Pengobatan Batimung dalam Masyarakat Banjar dan Dayak Meratus di Kalimantan Selatan. Jurnal Naditira Widya. Vol 12, No. 2. Hal : 147-158.

[10] Song, Shanshan. 2019. Research on Moral Eduction Value of Man Folk Culture Symbol. $3^{\text {rd }}$ International Conference on Culture, Education and Economic Development of Modren Society (ICCESE 2019) Vol 310: 1004-1006.

[11] Suryanata, Jamal. T. 2017. Pambatangan. Banjarbaru: Tahura Media. 
